\title{
Antioxidant Enzymes and Physiological Responses of Safflower (Carthamus tinctorius L.) to Iron Application, under Water Deficit Condition
}

\author{
Kayvan Fathi AMIRKHIZ, Majid Amini DEHAGHI*, Siavash HESHMATI
}

Shahed University, Faculty of Agriculture, Department of Agronomy, Tehran, Iran; fathikeivan@gmail.com; amini@shahed.ac.ir ("correspondingauthor);

heshmatisiavash@gmail.com

\begin{abstract}
The effect of soil and foliar iron $(\mathrm{Fe})$ application on the activity of some antioxidant enzymes and plant metabolites of Carthamus tinctorius L. (IL111), under water stress conditions was tested. The results showed that under drought stress conditions, the activity of ascorbate peroxidase, superoxide dismutase, polyphenol oxidase and catalase enzymes increased with soil application of Fe. In contrast, the activity of peroxidase enzyme under drought conditions increased with foliar application of Fe treatments. In general, leaf total soluble proteins, proline and malondialdehyde amounts were affected by interaction effects of drought stress and Fe. The results showed that leaf total soluble proteins had a positive reaction to soil and foliar applications of Fe. The result of this interaction effects showed that soil application of $\mathrm{Fe}$ is able to decrease malondialdehyde amount under water stress conditions. In addition, it was indicated that soil application of Fe in drought stress conditions lead to increasing proline. In conclusion, soil and foliar application of Fe during drought stress may counteract negative effects of such stress and enhance safflower tolerance to drought by increasing some antioxidant enzymes and plant metabolites (organic compounds such as proline and soluble proteins).
\end{abstract}

Keywords: Fe, osmotic regulator, plant metabolites, reactive oxygen species, water stress

\section{Introduction}

Drought or water deficit stress are major environmental factors that negatively impacts agricultural yield throughout the world, particularly when this kind of stress occurs during reproductive growth, affecting production, whether it is for subsistence or economic gain (Selote and Khana-Chopra, 2004). One of the biochemical changes occurring when plants are subjected to environmental stress is the production of reactive oxygen species (ROS) (Dat et al., 2000). Moreover, overproduction of ROS in plant cells under stress can damage cellular components, including DNA, proteins and membrane lipids (Mittler, 2002). To prevent or alleviate injuries from ROS, plants have evolved an antioxidant defense system that includes non-enzymatic compounds, such as ascorbate, glutathione, tocopherol, carotenoids and flavonoids, as well as enzymes, such as superoxide dismutase (SOD, EC; 1.15.1.1), catalase (CAT, EC; 1.11.1.6), peroxidase (POX, EC;1.11.1.7), ascorbate peroxidase (APX; EC 1.11.1.11) and polyphenol oxidase (PPO, EC; 1.10.3.1) (Agarwal and Pandey, 2004). The SOD-APX-CAT system protects the photosynthetic machinery from oxidative damage in plants exposed to environmental stress (Cavalcanti $e t$ al., 2004). SOD scavenges the $\mathrm{O}^{2-}$ generated by the electron transport chain in chloroplasts and mitochondria, and the $\mathrm{H}_{2} \mathrm{O}_{2}$ produced by SOD activity is then eliminated by APX in different cell compartments (Shigeoka et al., 2002). In addition, CAT removes the $\mathrm{H}_{2} \mathrm{O}_{2}$ generated in the photorespiration pathway inside peroxisomes (Mittler, 2002). Therefore, maintenance of a favorable balance between SOD, APX and CAT is essential to avoid ROS accumulation, to preserve the photochemical apparatus and to avoid significant oxidative damage (Guo et al., 2007). The activity of antioxidant enzymes play an important role in scavenging ROS and, therefore, their improvement could increase plants ability to tolerate stress and delay senescence (Alscher et al., 2002).

Plants have several protection mechanisms to prevent the damaging effect of ROS (Pietrini et al., 2002). For instance, osmotic adjustment is an important physiological adaptation for minimizing the detrimental effects of drought stress (Morgan, 1984). Osmotic adjustment is usually defined as a decrease in cell sap osmotic potential resulting from a net increase in intracellular solutes rather than from a loss of cell water. The former may operate through the concentration accretion of inorganic and/or organic solutes such as proline, glycine betaine, free amino acids, sugars, polyamines and polyphenols (Ben Khaled et al., 2003). Plants also accumulate osmotically active compounds (osmolytes) in the cytosol, allowing cells to regulate turgor pressure and to extract water from soil in water deficit conditions. Osmolytes help in maintaining the membrane structure and act as free radical scavengers, preventing lipid peroxidation and regulating $\mathrm{K}^{+}$ion channels in stomata (Roychoudhury et al., 2008; Sekmen et al., 2007). Proline is a reliable indicator of environmental stress imposed on plants (Claussen, 2005). Proline is capable of detoxifying free radicals by forming stable complexes with them, thus maintaining $\mathrm{NAD}(\mathrm{P})^{+} / \mathrm{NAD}(\mathrm{P}) \mathrm{H}$ ratios during stress at values similar to normal conditions (Sharma et al., 1998). 
204

Water stress can also modify plant nutrient availability, uptake and transport (Schulze, 1991).

Iron is considered an essential nutrient for plant growth and plays a central role on the overall physiology of plants. Plants subject to iron deficiency stress suffer a range of deleterious effects including inhibition of photosynthesis processes, pigment synthesis and other metabolic disturbances such as change in activity levels of several metalloenzymes (Manthey and Crowley, 1997). Iron deficiency is commonly observed in soils with high acidity and in lime soils of dry lands. Likewise, extra bicarbonates of irrigation water and soil may either deteriorate Fe deficiency or decrease Fe absorption in soils with low organic content (Havlin et al., 2005). Moreover, it has been shown that many enzymes require iron to function correctly. In particular, iron is present in the active sites of catalase and superoxide dismutase involved in the scavenging of ROS, as previously described by Elstner and Osswald (1994). Iron deficiency in plants not only causes chlorosis, but also reduces the activity of certain enzymes that contain Fe porphyrin as prosthetic groups, such as catalase and peroxidase (Balakrishnan, 2000).

Considering the usual Fe deficiency in soils of dry regions, this study aims to understand the effect of soil and foliar Fe applications, in various levels, on the activity of several antioxidant enzymes and osmotic active compounds in safflower under water deficit conditions. The intention was to decrease the detrimental effects of stress in this oilseed crop by identifying effective mechanisms to cope with drought stress.

\section{Materials and methods}

\section{Experimental design}

The experiment was carried out at Shahed University, Tehran, farm $\left(35^{\circ} 33^{\prime} \mathrm{N}\right.$ and $\left.51^{\circ} 20^{\prime} \mathrm{E}\right)$, during the $2012 \mathrm{crop}$ season. The experimental site is located at 1,190.8 meters above sea level. Long-term (30 years) mean annual rainfall and temperature are $238.9 \mathrm{~mm}$ and $17.7{ }^{\circ} \mathrm{C}$, respectively. Minimum and maximum average temperatures and rainfall amounts during the crop season are summarized in Table 1. Mixed soil samples were prepared from $0-30$ and $30-60 \mathrm{~cm}$ of depth and then the soil texture, $\mathrm{pH}$, electrical conductivity (EC), total nitrogen, absorbable $\mathrm{P}, \mathrm{K}, \mathrm{Fe}, \mathrm{Zn}$ and $\mathrm{Mn}$ were measured prior to planting. The results of soil and water physical and chemical analyses were shown in Table 2 . The soil type was classified as loam, and Fe values were lower than the critical level. Soil and water of the experimental site were free from salty limitation. The consumed nitrogen fertilizer amount was $150 \mathrm{~kg} \mathrm{~N} \mathrm{ha}{ }^{-1}$ urea, at the beginning of plantation. Each furrow was $2 \times 4 \mathrm{~m}^{2}$ and included 4 plantation rows separated by $50 \mathrm{~cm}$. Each row was of 4 meters long and a free row was set between all furrows. The distance between plants was $5 \mathrm{~cm}$; therefore, the final density was of approximately 400,000 plants $/ \mathrm{ha}^{-1}$. The experimental design was split plot in a randomized complete blocks design (CRBD) with 4 replicates. The factors were: drought stress with two levels (normal irrigation or irrigation to reach 50\% soil moisture depletion of field capacity (I1) and irrigation from the beginning of flowering to the end of pollination stage, reaching $75 \%$ of soil moisture depletion of field capacity (I2) in the main plots, and soil application of Fe-EDDHA and application of water with eight levels $(\mathrm{S} 1=$ without soil application of Fe, $S 2=50, S 3=100, S 4=150 \mathrm{Fe} \mathrm{Kg} \mathrm{h}^{-1}, \mathrm{~F} 1=$ foliar application of water, F2 = 1,000, F3=2,000 and F4= $3,000 \mathrm{Fe} \mathrm{mg.L^{-1 }}$ ) in the subplots.
Table 1.Monthly temperature and precipitation during the growing season 2012

\begin{tabular}{ccccc}
\hline \multirow{2}{*}{$\begin{array}{c}\text { Total precipitation } \\
(\mathrm{mm})\end{array}$} & \multicolumn{3}{c}{ Average temperature $\left({ }^{\circ} \mathrm{C}\right)$} & \multirow{2}{*}{ Month } \\
\cline { 2 - 4 } & Mean & Maximum & Minimum & \\
\hline 0.59 & 16.42 & 22.115 & 10.73 & March \\
1.01 & 17.72 & 22.83 & 12.615 & April \\
0.27 & 24.02 & 29.095 & 18.95 & May \\
0.115 & 28.04 & 34.05 & 22.035 & June \\
0 & 31.605 & 37.74 & 25.475 & July \\
\hline
\end{tabular}

Table 2. Physico-chemical properties of the soil and characteristics of water used for irrigation and foliar spraying

\begin{tabular}{llll}
\hline Soil properties & Values & Water characteristics & Values \\
\hline $\mathrm{EC}\left(\mathrm{dSm}^{-1}\right)$ & 4.96 & $\mathrm{EC}\left(\mathrm{dSm} \mathrm{m}^{-1}\right)$ & 2.18 \\
$\mathrm{pH}$ & 7.7 & $\mathrm{pH}$ & 7.7 \\
Organic carbon $(\%)$ & 1 & $\mathrm{Ca}^{2+}\left(\right.$ mequiv. $\left.\mathrm{l}^{-1}\right)$ & 0.9 \\
Total N $(\%)$ & 0.089 & $\mathrm{Mg}^{2+}\left(\right.$ mequiv. $\left.\mathrm{l}^{-1}\right)$ & 0.6 \\
Available P $\left(\mathrm{mgkg}^{-1}\right)$ & 16 & $\mathrm{Na}^{+}\left(\right.$mequiv. $\left.\mathrm{l}^{-1}\right)$ & 19 \\
Available K $\left(\mathrm{mgkg}^{-1}\right)$ & 320 & $\mathrm{SAR}$ & 22.09 \\
$\mathrm{Fe}\left(\mathrm{mg} \mathrm{kg}^{-1}\right)$ & 2.8 & $\mathrm{Cl}^{-}\left(\right.$mequiv. $\left.\mathrm{l}^{-1}\right)$ & 16.5 \\
$\mathrm{Zn}\left(\mathrm{mg} \mathrm{kg}^{-1}\right)$ & 2.4 & $\mathrm{HCO}_{3}\left(\right.$ mequiv. $\left.\mathrm{l}^{-1}\right)$ & 2 \\
$\mathrm{Mn}\left(\mathrm{mg} \mathrm{kg}^{-1}\right)$ & 14 & $\mathrm{TDS}\left(\mathrm{mgl}^{-1}\right)$ & 1395 \\
\hline
\end{tabular}

Soil and foliar applications of Fe were conducted during flowering, under drought stress. All experimental plots were simultaneously and equally irrigated up to the beginning of flowering and pollination stages. After that, all plots without drought stress were irrigated up to the end of the season and yellowing leaves, while drought-stressed plots were irrigated only after determination of soil moisture to achieve $75 \%$ of moisture depletion of field capacity. Soil moisture was measured by a gravimetric method, which consisted of extracting a soil sample from $0-30 \mathrm{~cm}$ depth at 48 hours after irrigation, immediately weighting and transferring the sample to a $100^{\circ} \mathrm{C}$ oven, to measure soil moisture weight percentage. Thus, prior to re-irrigation, the soil moisture was allowed to achieve $75 \%$ moisture depletion of field capacity at root depth.

\section{Antioxidant enzyme assays \\ Sampling}

In the end of the flowering stage, youngest leaves were sampled. After washing, leaves were frozen in liquid $\mathrm{N}_{2}$ and stored at $-80^{\circ} \mathrm{C}$ until biochemical analysis.

\section{Extract preparation}

Frozen leaves $(0.2 \mathrm{~g})$ were homogenized using a mortar and pestle with $3 \mathrm{~mL}$ ice-cold extraction buffer $(25 \mathrm{~mm}$ sodium phosphate buffer, $\mathrm{pH}=7.8$ ). The homogenate was centrifuged at $18,000 \mathrm{~g}$ for $30 \mathrm{~min}$ at $4{ }^{\circ} \mathrm{C}$. Then, the supernatant was passed through filter paper and it was used for the determination of enzyme activity and protein content as a crude extract.

Catalase activity was estimated by the method of Cakmak and Horst (1991). The decrease in absorbance was recorded at $240 \mathrm{~nm}$ for $1 \mathrm{~min}$ using a spectrophotometer. Catalase activity of the extract was expressed as $\Delta \mathrm{A} \mathrm{mg}^{-1}$ protein $\mathrm{min}^{-1}$. Superoxide dismutase activity was determined by measuring the ability of the enzyme extract to inhibit the photochemical reduction of nitrobluetetrazolium (NBT) according to the method of Giannopolitis and Ries (1977). The absorbance was measured at $560 \mathrm{~nm}$ and one unit of SOD activity was 
defined as the amount of enzyme that caused 50\% inhibition of photochemical reduction of NBT. Superoxide dismutase activity of the extract was expressed as $\Delta \mathrm{A} \mathrm{mg}^{-1}$ protein $\mathrm{min}^{-1}$. Peroxidase and polyphenol oxidase activity were estimated using the method of Ghanati et al. (2002). Peroxidase enzyme activity was determined by the oxidation of guaiacol in the presence of $\mathrm{H}_{2} \mathrm{O}_{2}$. The increase in absorbance at $470 \mathrm{~nm}$ was recorded in a spectrophotometer for $1 \mathrm{~min}$. The reaction mixture contained $100 \mu \mathrm{L}$ of crude extract, $500 \mu \mathrm{L}$ of $5 \mathrm{mM}$ $\mathrm{H}_{2} \mathrm{O}_{2}, 500 \mu \mathrm{L}$ of $28 \mathrm{mM}$ guaiacol and $1,900 \mu \mathrm{L}$ of $60 \mathrm{mM}$ potassium phosphate buffer ( $\mathrm{pH}$ 6.1). POX activity of the

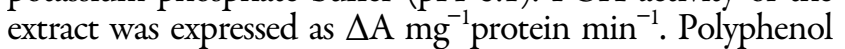
oxidase enzyme activity was determined by the oxidation of catechol in the presence of $\mathrm{H}_{2} \mathrm{O}_{2}$. The increase in absorbance at $410 \mathrm{~nm}$ was recorded in a spectrophotometer for $1 \mathrm{~min}$. The activity of PPO enzymes in the extract was expressed as $\Delta \mathrm{A} \mathrm{mg}$ protein $\mathrm{min}^{-1}$. APX activity was assayed by measuring the decrease in absorbance at $290 \mathrm{~nm}(\varepsilon=2.8$ $\mathrm{mM}^{-1} \mathrm{~cm}^{-1}$ ) for $1 \mathrm{~min}$ (Nakano and Asada, 1981). The reaction was initiated with $\mathrm{H}_{2} \mathrm{O}_{2}$. Rates were corrected by subtracting rates occurring in the absence of enzyme extract. The activity of each enzyme was expressed on a protein basis.

\section{Total leaf soluble protein content}

Total protein content was determined using bovine serum albumin (BSA) as a standard, according to the method of Bradford (1976), using $1 \mathrm{ml}$ Bradford solution and $100 \mathrm{ml}$ crude extract. Coomassie Blue G 250 (100 $\mathrm{mg}$ ) was dissolved in $50 \mathrm{ml}$ of methanol. The solution was added to $100 \mathrm{ml}$ of $85 \% \mathrm{H}_{3} \mathrm{PO}_{4}$ and diluted to $200 \mathrm{ml}$ with distilled water. Protein concentration was calculated from a BSA standard curve.

Malondialdehyde concentration (level of lipidperoxidation)

The level of membrane damage was determined by measuring the amount of malondialdehyde (MDA), which is the end product of lipid peroxidation, according to the DeVos et al. (1991) method. The amount of MDA in the samples was determined from the absorbance at $532 \mathrm{~nm}$, followed by correction for non-specific absorbance at $600 \mathrm{~nm}$ in a spectrophotometer. Concentration of MDA was determined by the extinction coefficient of MDA ( $\varepsilon$ $\left.=155 \mu \mathrm{M}^{-1} \mathrm{~cm}\right)$.

\section{Proline content}

Proline content of leaves was determined according to a modification of the method of Bates et al. (1973). The absorbance was measured at $520 \mathrm{~nm}$ using a spectrophotometer. The content of proline was calculated from a standard curve and was expressed as $\mathrm{mg}$ $\mathrm{g} \mathrm{FW}^{-1}$.

\section{Statistical analysis}

The data were analyzed using analysis of variance (ANOVA) using the GLM procedure in SAS (SAS Institute Inc, 2002) $(\mathrm{P}<0.01)$. The assumptions of the ANOVA were tested by ensuring that the residuals were random and homogenous, with a normal distribution and with a mean of approximately zero. The significance of differences among treatment means was tested using LSMEANS with the PDIFF option.

\section{Results and discussions}

\section{Antioxidant enzyme activities}

Results of the interactive effects of drought and Fe stress showed that a change in the CAT activity in I1, due to the soil or foliar application of Fe, was observable. The highest activity of CAT was obtained in S2. The increase in CAT activity under S2 was $61 \%$ in comparison with S1. However, during the drought stress and decreased soil moisture of up to $75 \%$ of the field capacity (I2), CAT positively responded to Fe application. In addition, S2 significantly increased the CAT activity rate under I2 compared with $\mathrm{F} 1$, which demonstrated a 3.2- and 4-fold increase, whereas S2, compared with $S 1$, showed a 2- and 1.3-fold increase, respectively (Fig. 1).

CATs are tetramericheme-containing enzymes with the potential to directly dismutase $\mathrm{H}_{2} \mathrm{O}_{2}$ into $\mathrm{H}_{2} \mathrm{O}$ and $\mathrm{O}_{2}$; they are essential for ROS detoxification during stress conditions (Garg and Manchanda, 2009). The microelements such as Fe, $\mathrm{Zn}, \mathrm{Cu}, \mathrm{Mg}$ and $\mathrm{Mn}$ also play roles as cofactors of many antioxidant enzymes; therefore, when plants are deficient of these elements, the activities of antioxidant enzymes decrease and plants become more sensitive to environmental stresses (Kabata-Pendias and Pendias, 1999). Therefore, Fe application resulted in an increase of the CAT activity in the safflower leaves under water deficit conditions, which could be due to higher availability of Fe in soil.

Interactions between drought stress and Fe application resulted in the Fe treatments, on several levels of drought stress, being classified in different statistical classes in terms of the APX activity. Our results indicated that Fe affected the APX activity of safflower during the flowering stage under I2. The highest APX activity was obtained with the S4 and S3 treatments; however, no significant differences were observed with S2 and F2, and the lowest APX activity was obtained with F1. With an increase in the soil moisture from 75 to $50 \%$ of the field capacity (I1), the trend in the APX activity was proportional to the Fe levels; namely, the highest APX average corresponded to S3. Similarly, the lowest activity of the enzyme was observed in F1 under the I1 condition. In this study, the APX activity increased with the Fe levels, such that the highest and lowest APX activities were obtained with S4 and F1, respectively. Similarly, the lowest APX activity was observed with F1 under the I1 conditions (Fig. 2).

The expression of APX has been reported to be regulated by $\mathrm{Fe}$ in higher plants. APX is a heme-containing enzyme, similar to other peroxidases and catalases (Shigeoka et al., 2002). Zaharieva and Abadia (2003) reported that the activity of APX decreased under stress conditions, including Fedeficiency in sugar beet. Regarding to results of this experiment, using Fe can increased APX activity under drought stress.

Our results demonstrated a strong interaction effect between the drought stress levels and Fe in terms of the PPO activity. With a $25 \%$ increase of soil moisture depletion (I2 instead of I1) and with the S3 application of Fe, the highest activity of PPO was observed. However, under water-deficit conditions (I2), the S4 application decreased the PPO amount by $74.1 \%$ in comparison with S3. In contrast, with increasing soil moisture from $75 \%$ to $50 \%$ of the field capacity (I1), the F3 treatment resulted in a higher activity of this enzyme, to approximately 2.5 -fold more than with the F1 treatment (Fig. 3). 


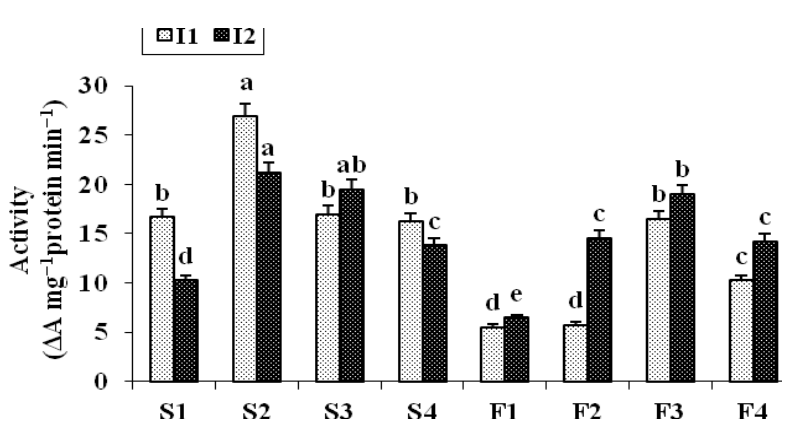

Fig. 1. Changes in catalase activity due to water deficit stress and application of Fe; I1- normal irrigation or irrigation to reach 50\% soil moisture depletion of field capacity, I2- irrigation from the beginning of flowering to the end of pollination stage reaching $75 \%$ of soil moisture depletion of field capacity; S- soil application of Fe, S1- without soil application of Fe; S2- $50 \mathrm{Fe} \mathrm{Kg} \mathrm{ha}^{-1}$, S3- $100 \mathrm{Fe} \mathrm{Kg} \mathrm{ha}^{-1}, \mathrm{~S} 4-150 \mathrm{Fe} \mathrm{Kg}$ $\mathrm{ha}^{-1}$; F- foliar application of Fe, F1- foliar application of water, F2- 1,000 Fe mg $\mathrm{l}^{-1}$, F3- 2,000 Fe mg l-1, F4- 3,000 Fe mg $\mathrm{l}^{-1}$; LS MEANS within each column of each section followed by the same letter are not significantly different $(\mathrm{p} \leq 0.05)$

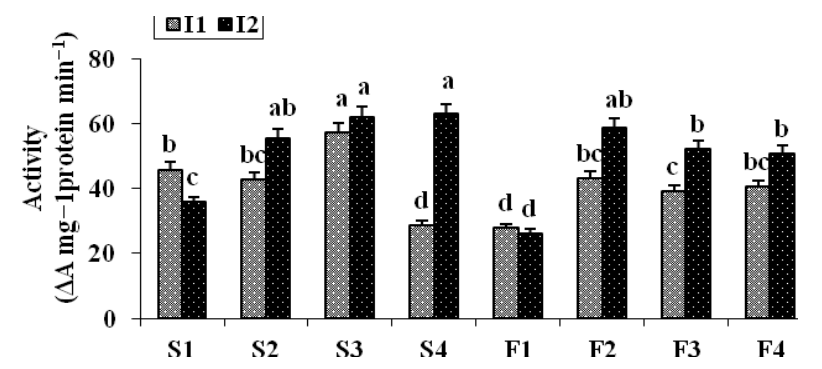

Fig. 2. Changes in ascorbate peroxidase activity due to water deficit stress and application of Fe; I1- normal irrigation or irrigation to reach 50\% soil moisture depletion of field capacity, I2-irrigation from the beginning of flowering to the end of pollination stage reaching $75 \%$ of soil moisture depletion of field capacity; S- soil application of Fe, S1- without soil application of Fe; S2- $50 \mathrm{Fe} \mathrm{Kg} \mathrm{ha}^{-1}$, S3- $100 \mathrm{Fe} \mathrm{Kg} \mathrm{ha}^{-1}$, S4- $150 \mathrm{Fe} \mathrm{Kg}$ $\mathrm{ha}^{-1}$; F- foliar application of Fe, F1- foliar application of water, F2-1,000 Fe mg l-1 ${ }^{-1}$ F3- 2,000 Fe mg l-1, F4- 3,000 Fe $\mathrm{mg} \mathrm{l}^{-1}$; LS MEANS within each column of each section followed by the same letter are not significantly different $(\mathrm{p} \leq 0.05)$

Thipyapong et al. (2007) reported that if PPO contributes to the Mehler reaction, then plants with elevated PPO are expected to have improved stress tolerance because photosynthetic electron transport can reduce molecular oxygen $\left(\mathrm{O}_{2}\right)$, yielding superoxide, a ROS that is capable of damaging or inactivating essential macromolecules (Halliwell and Gutteridge, 1999). Therefore, a higher activity of PPO under drought stress after the addition of Fe to the soil indicates an enhanced plant tolerance to drought stress.

The POX activity under drought stress followed a similar trend with the soil and foliar applications: F2 significantly increased the POX activity rate under $\mathrm{I} 2$ compared with $\mathrm{F} 1$, which showed a 1.9- fold increase. Furthermore, S1 showed a 4.5-fold increase. The lowest activity of this enzyme was observed in S1 under the $\mathrm{I} 2$ condition. Our results showed that under optimal moisture conditions ( $50 \%$ of the field capacity) the POX activity increased through S3 and S2, although no significant differences

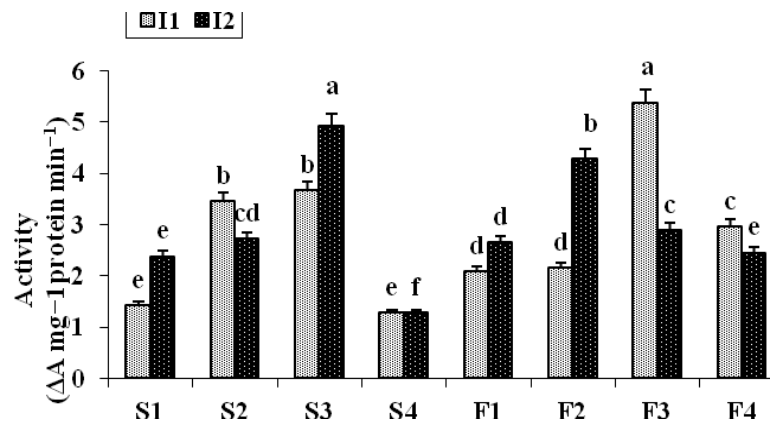

Fig. 3. Changes in polyphenol oxidase activity due to water deficit stress and application of Fe; I1- normal irrigation or irrigation to reach 50\% soil moisture depletion of field capacity, I2-irrigation from the beginning of flowering to the end of pollination stage reaching $75 \%$ of soil moisture depletion of field capacity; S- soil application of Fe, S1- without soil application of Fe; S2- $50 \mathrm{Fe} \mathrm{Kg} \mathrm{ha}^{-1}$, S3- $100 \mathrm{Fe} \mathrm{Kg} \mathrm{ha}^{-1}$, S4- $150 \mathrm{Fe} \mathrm{Kg}$ $\mathrm{ha}^{-1}$; F- foliar application of Fe, F1- foliar application of water, F2- 1,000 Fe mg l-1, F3- 2,000 Fe mg l-1, F4- 3,000 Fe $\mathrm{mg} \mathrm{l}^{-1}$; LS MEANS within each column of each section followed by the same letter are not significantly different $(\mathrm{p} \leq 0.05)$

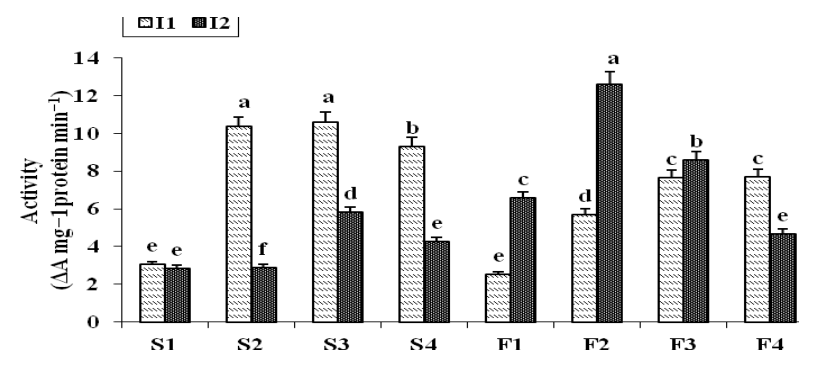

Fig. 4. Changes in peroxidase activity due to water deficit stress and application of Fe; I1- normal irrigation or irrigation to reach $50 \%$ soil moisture depletion of field capacity, I2- irrigation from the beginning of flowering to the end of pollination stage reaching $75 \%$ of soil moisture depletion of field capacity; S- soil application of Fe, S1- without soil application of Fe; S2- $50 \mathrm{Fe} \mathrm{Kg} \mathrm{ha}^{-1}$, S3- $100 \mathrm{Fe} \mathrm{Kg} \mathrm{ha}^{-1}$, S4- $150 \mathrm{Fe} \mathrm{Kg}$ $\mathrm{ha}^{-1}$; F- foliar application of Fe, F1- foliar application of water, F2- 1,000 Fe $\mathrm{mgl}^{-1}$, F3- 2,000 Fe $\mathrm{mg} \mathrm{l}^{-1}$, F4- 3,000 $\mathrm{Fe} \mathrm{mg} \mathrm{l}^{-1}$; LS MEANS within each column of each section followed by the same letter are not significantly different $(\mathrm{p} \leq 0.05)$

were observed between them. The F1 and S1 treatments had the lowest effect on the POX activity under the I1 condition (Fig. 4). Ranieri et al. (2001) reported that POX isoenzyme patterns of soybean and sunflower leaves grown in nutrient solution are affected by iron starvation and showed preferential reduction in their activity in a detoxification process. The data suggest that the increased POX activity upon the application of Fe led to a decrease in the oxidative stress in the safflower under water deficit conditions.

Similarly, the differences in SOD activity under the drought stress and Fe treatments were significant. Under a 50\% moisture depletion of the field capacity, the Fe application did not have a considerable effect on the SOD activity, while its activity increased with S1. However, with increasing soil moisture depletion from 50 to $75 \%$ of the field capacity, the SOD activity showed a positive reaction to the application of Fe because the trend in SOD activity was proportional with the Fe levels; namely, the highest SOD 


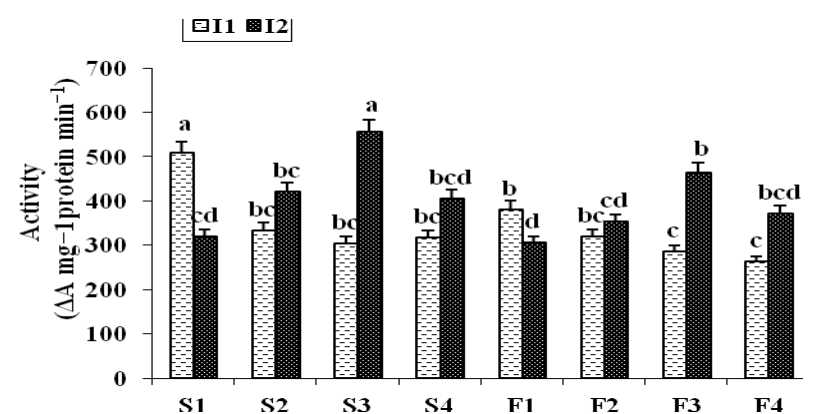

Fig. 5. Changes in superoxide dismutase activity due to water deficit stress and application of Fe;. I1- normal irrigation or irrigation to reach $50 \%$ soil moisture depletion of field capacity, I2- irrigation from the beginning of flowering to the end of pollination stage reaching $75 \%$ of soil moisture depletion of field capacity; S- soil application of Fe, S1without soil application of Fe; S2- $50 \mathrm{Fe} \mathrm{Kg} \mathrm{ha}^{-1}$, S3- $100 \mathrm{Fe} \mathrm{Kg} \mathrm{ha}^{-1}$, S4$150 \mathrm{Fe} \mathrm{Kg} \mathrm{ha}^{-1}$; F- foliar application of Fe, F1- foliar application of water, F2- 1,000 Fe mgl $^{-1}$, F3- 2,000 Fe $\mathrm{mgl}^{-1}$, F4- 3,000 Fe mgl-1 $^{-1}$; LS MEANS within each column of each section followed by the same letter are not significantly different $(\mathrm{p} \leq 0.05)$

activity corresponded to S3. Our results showed that S3 increased the SOD activity by approximately $73.2 \%$ and $81.6 \%$ compared with $S 1$ and F1, respectively. In addition, the highest foliar application of Fe (F4) resulted in the least SOD activity. Thus, our results indicated that Fe applications to the soil are useful for SOD activity under drought conditions (Fig. 5).

The SOD, CAT and GPX activities increased with Fe, Zn, $\mathrm{Mn}$ and $\mathrm{Cu}$ in sunflower as reported by Rahimizadeh et al. (2007). SODs are classified by their metal cofactors into three types: copper/zinc ( $\mathrm{Cu} / \mathrm{Zn}-\mathrm{SOD})$, manganese (Mn-SOD) and iron (Fe-SOD). They are localized in different cellular compartments (Mittler, 2002). Other microelements, such as $\mathrm{Fe}, \mathrm{Zn}, \mathrm{Cu}, \mathrm{Mg}$ and $\mathrm{Mn}$, are cofactors in the structures of many antioxidant enzymes; therefore, when plants are deficient of these elements, the activities of antioxidant enzymes decrease, thereby imposing higher sensitivity to environmental stresses (Kabata-Pendias and Pendias, 1999). It appears that the soil application of Fe with $100 \mathrm{Kg} \mathrm{ha}^{-1}$ (S3) can increased SOD activity under drought stress, because of elevated levels of this enzyme activity in safflower leaves that may reduce the oxidative stress damage.

\section{Total leaf soluble protein content}

The results showed that under the studied drought stress levels, there was a significant difference between the Fe treatments in terms of the total leaf soluble proteins. The average of the total leaf soluble proteins, with three levels of Fe soil applications (S2 to S4) and three levels of foliar application (F2 to F4) under water stress, were $0.414 \mathrm{mg} \mathrm{g} \mathrm{FW}^{-1}$ and $0.413 \mathrm{mg} \mathrm{g}^{-1}$ $\mathrm{FW}^{-1}$, respectively, which were higher than the $0.120 \mathrm{mg} \mathrm{g} \mathrm{FW}^{-1}$ and $0.123 \mathrm{mg} \mathrm{g} \mathrm{FW}^{-1}$ with $\mathrm{S} 1$ and F1, respectively. The total leaf soluble proteins during flowering after decreasing the soil moisture from $50 \%$ to $75 \%$ of the field capacity significantly increased in F4, whereas F3 and F2 were ranked as the second and third options for enhancing the total leaf soluble proteins and were therefore classified into a superior group. The interaction effects of the drought stress and Fe showed that S4 under the non-stress condition gained the highest total leaf soluble protein content, with $0.493 \mathrm{mg} \mathrm{g} \mathrm{FW}^{-1}$. The results

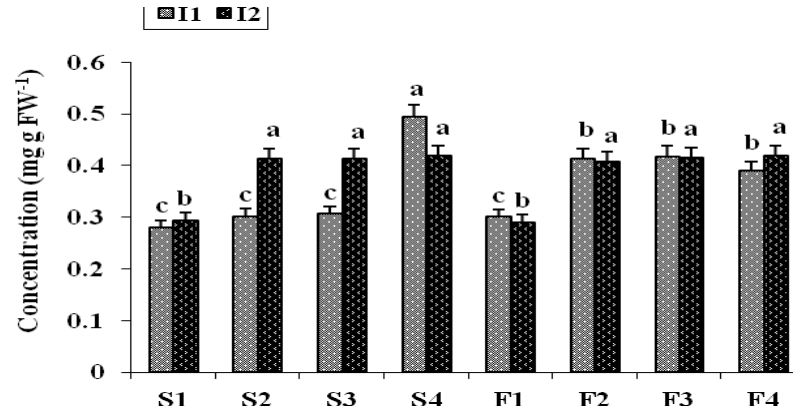

Fig. 6. Changes in protein content due to water deficit stress and application of Fe; I1- normal irrigation or irrigation to reach $50 \%$ soil moisture depletion of field capacity, I2- irrigation from the beginning of flowering to the end of pollination stage reaching $75 \%$ of soil moisture depletion of field capacity; S- soil application of Fe, S1- without soil application of Fe; S2- $50 \mathrm{Fe} \mathrm{Kg} \mathrm{ha}^{-1}$, S3- $100 \mathrm{Fe} \mathrm{Kg} \mathrm{ha}^{-1}$, S4- $150 \mathrm{Fe} \mathrm{Kg}$ $\mathrm{ha}^{-1}$; F- foliar application of Fe, F1- foliar application of water, F2- 1,000 Fe mg l-1, F3- 2,000 Fe mg l-1, F4- 3,000 Fe $\mathrm{mg} \mathrm{l}^{-1}$; LS MEANS within each column of each section followed by the same letter are not significantly different $(\mathrm{p} \leq 0.05)$

showed a decrease in total leaf soluble proteins content in I1 condition by S1, F1, S2 and S3. Under the non-stress conditions, where the total leaf soluble proteins had the maximum value, the activity level of the antioxidant enzymes was approximately zero. The interactive effects of drought and Fe on the soluble proteins of the leaf indicated that the soil and foliar application of Fe increased the proteins under drought stress in comparison with the control treatments, $S 1$ and F1 (Fig. 6).

Micronutrients are present in small amounts and they activate approximately 100 enzymes in a variety of plants. Plants are not able to survive without micronutrients because they are essential for DNA and RNA synthesis, as well as for metabolizing carbohydrates, fats, proteins and alcohols (Marschner, 1995). Also, Nagaraj (1987) in order to study the effect of foliar micronutrients such as $\mathrm{Mn}, \mathrm{Fe}$, Mo and $\mathrm{Mg}$ on peanut observed that $\mathrm{Fe}$ increased total leaf soluble protein content. Hence, their availability for plants is vital. Similarly, Fe application had a positive influence on the soluble protein content of safflower leaves under drought stress conditions in this experiment.

\section{Proline content}

The application of $\mathrm{Fe}$ affected the proline accumulation under $\mathrm{I} 2$ and the highest value of proline accumulation was obtained with S2. In addition, the lowest value of proline was observed in S1 and F1 under I2 conditions, while with a 50\% moisture depletion of the field capacity, the effect of foliar $\mathrm{Fe}$ application on proline was positive, and the proline content was enhanced with higher levels of foliar application. The highest proline was obtained with F4. The results showed that the combination of I1 F4 with $0.0577 \mathrm{mg} \mathrm{g} \mathrm{FW}^{-1}$, in comparison with I1 F1 with $0.0292 \mathrm{mg} \mathrm{g} \mathrm{FW}^{-1}$, was significantly superior and an increase in proline was $97.4 \%$ (Fig. 7 ).

Proline may have different roles in drought-resistance mechanisms, such as scavenging free radicals and thereby, protecting cellular structures against oxidative damage and denaturation (Girija et al., 2002). Moreover, Yoshiba et al. (1997) and Phutela et al. (2000) suggested that proline accumulates in tissues of stressed plants due to the increased 
圆I1 日I2

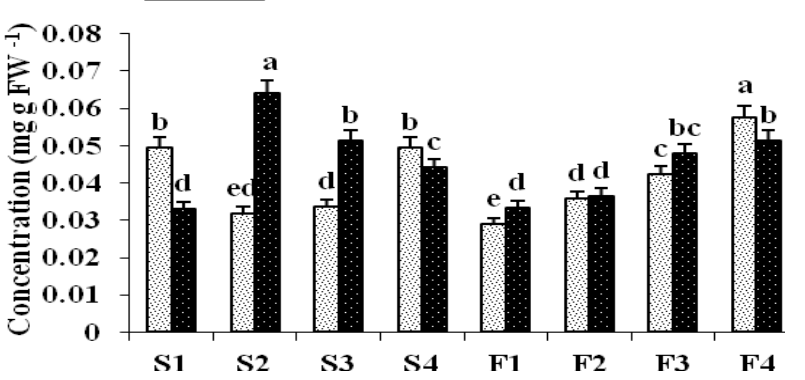

Fig. 7. Changes in proline content due to water deficit stress and application of Fe; I1- normal irrigation or irrigation to reach $50 \%$ soil moisture depletion of field capacity, I2- irrigation from the beginning of flowering to the end of pollination stage reaching $75 \%$ of soil moisture depletion of field capacity; S- soil application of Fe, S1- without soil application of Fe; S2- 50 Fe Kg ha ${ }^{-1}$, S3- $100 \mathrm{Fe} \mathrm{Kg} \mathrm{ha}^{-1}$, S4- $150 \mathrm{Fe} \mathrm{Kg}$ $\mathrm{ha}^{-1}$; F- foliar application of Fe, F1- foliar application of water, F2- 1,000 Fe mg l-1, F3- 2,000 Fe mg l-1, F4- 3,000 Fe mg ${ }^{-1}$; LS MEANS within each column of each section followed by the same letter are not significantly different $(\mathrm{p} \leq 0.05)$

rate of its synthesis by pyrroline-5-carboxylate synthetase and then it decreases as it is degradated by proline oxidase enzyme, with concomitant increases in both cell turgidity and its activity. It seems that increase in proline content with Fe application could improve safflower tolerance to water deficit condition.

\section{Malondialdehyde concentration}

Major changes in the MDA amounts resulted from the interactive effects of drought stress and $\mathrm{Fe}$. The results of this effect showed that by increasing the soil moisture from $75 \%$ to $50 \%$ of the field capacity, the MDA amount was significantly decreased by S4 $\left(0.127 \mu \mathrm{M} \mathrm{cm}^{-1}\right)$ in comparison with the other Fe treatments. The comparison of the means showed that the combination of I2

S4 decreased the MDA amount by $45.6 \%$ compared with $\mathrm{I} 2$ F1, therefore MDA was enhanced due to drought stress, particularly with the F1 treatment (Fig. 8).

Cell membranes are among the first and major ultra structural sites to be affected by ROS, which may disturb membrane function. Symptoms of those unfavorable processes include: oxidation of unsaturated fatty acids, protein degradation, and the resultant loss of selective permeability of membranes (Senaratna and McKersie, 1986). Lipid peroxidation measured as the amount of thiobarbituric acid reactive substance or malondialdehyde (TBARS or MDA) is produced when polyunsaturated fatty acids in the membrane undergo oxidation by the accumulation of free oxygen radicals. As lipid peroxidation is the symptom mostly ascribed to oxidative damage, it is often used as an indicator of increased damage (Hernandez et al., 2000).

The increase in TBARS under iron deficiency indicates that iron deficiency induced oxidative damage on lipids and proteins (Sun et al., 2007). Also, the increased accumulation of LPO is indicative of enhanced production of toxic oxygen species. Likewise, the level of MDA (one of the major TBA reaction metabolites) increased in iron-deficient borage plantlets (Mohamed and Aly, 2004). In this study it was determined that reducing the amount of $\mathrm{MDA}$ at different levels of $\mathrm{Fe}$ under drought stress could compensate the negative effects of stress.

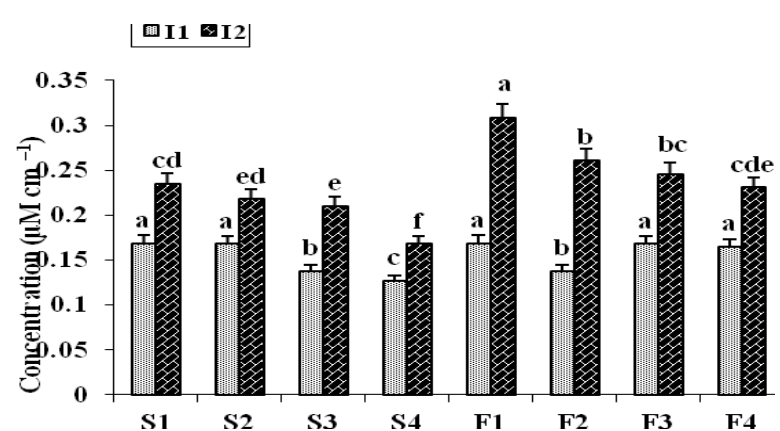

Fig. 8. Changes in malondialdehyde content due to water deficit stress and application of Fe; I1- normal irrigation or irrigation to reach $50 \%$ soil moisture depletion of field capacity, I2-irrigation from the beginning of flowering to the end of pollination stage reaching $75 \%$ of soil moisture depletion of field capacity; S- soil application of Fe, S1- without soil application of Fe; S2- 50 Fe Kg ha ${ }^{-1}$, S3- $100 \mathrm{Fe} \mathrm{Kg} \mathrm{ha}^{-1}$, S4- $150 \mathrm{Fe} \mathrm{Kg}$ $\mathrm{ha}^{-1}$; F- foliar application of Fe, F1- foliar application of water, F2- 1,000 Fe mg l-1, F3- 2,000 $\mathrm{Fe} \mathrm{mg} \mathrm{l-1}^{-1}$, F4- 3,000 Fe $\mathrm{mg} \mathrm{l}^{-1}$; LS MEANS within each column of each section followed by the same letter are not significantly different $(\mathrm{p} \leq 0.05)$

\section{Conclusions}

According to our findings, both the soil and foliar application of Fe had a positive effect on the activities of the antioxidant enzymes and certain metabolites under water stress conditions. Considering the warm and dry climate of the region where the experiment was carried out, either the soil or foliar Fe application could be useful. Under these conditions, however, the high temperatures could increase the amount of evaporation because the foliar application of the Fe salts may lead to burned leaves. Therefore, the application of Fe to the soil may be more appropriate than the foliar method. As a result, soil Fe application is highly recommended to minimize the possible damage due to drought stress during flowering and to extend the cultivated area of oil grain crops, such as the safflower, in dry and semidry regions with limited irrigation during the springtime.

\section{References}

Agarwal S, Pandey V (2004). Antioxidant enzyme responses to $\mathrm{NaCl}$ stress in Cassia angustifolia. Biol Plant 48:555-560.

Alscher RG, Erturk N, Heath LS (2002). Role of superoxide dismutases in controlling oxidative stress in plants. J Exp Bot 53:1331-1341.

Balakrishnan K (2000). Peroxidase activity as an indicator of the iron deficiency in banana. Ind J Plant Physiol 5:389-391.

Bates LS, Waldern RP, Teave ID (1973). Rapid determination of free proline for water stress studies. Plant Soil 39:205-207.

Ben Khaled L, Morte-Gomez A, Honrubia M, Oihabi A (2003). Effet du stress salin en milieu hydroponique sur le trèfle inoculé par le Rhizobium. Agronomie 23:553-560.

Bradford MA (1976). Rapid and sensitive method for the quantitation of protein utilizing the principle of protein-dye binding. Annu Rev Biochem 72:248-254.

Cakmak I, Horst W (1991). Effect of aluminium on lipid peroxidation, superoxide dismutase, catalase and peroxidase activities in root tip of soybean (Glysin max). Plant Physiol 83:463-468. 
Cavalcanti FR, Oliveira JTA, Martins-Miranda AS, Viegas RA, Silveira JAG (2004). Superoxide dismutase, catalase and peroxidase activities do not confer protection against oxidative damage in saltstressed cowpea leaves. New Phytol 163:563-571.

Claussen W (2005). Proline as a measure of stress in tomato plants. Plant Sci 168:241-248.

Dat J, Vandenabeele S, Vranova E, Van Montagu M, Inze D, Van Breusegem $F(2000)$. Dual action of the active oxygen species during plant stress responses. Cell Molec Life Sci 57:779-795.

De Vos C, Schat HM, De Waal MA, Vooijs R, Ernst W (1991). Increased to copper-induced damage of the root plasma membrane in copper tolerant silene cucubalus. Plant Physiol 82:523-528.

Elstner F, Osswald W (1994). Mechanism of oxygen activation during plant stress. Proc R Sci Edinb 102:131-154.

Garg N, Manchanda G (2009). ROS generation in plants: boon or bane? Plant Biosys 143:8-96.

Ghanati F, Morita A, Yokota H (2002). Induction of suberin and increase of lignin content by excess boron in tobacco cell. Soil Sci Plant Nutr 48:357-364.

Giannopolitis C, Ries S (1977). Superoxide dismutase occurrence in higher plant. Plant Physiol 59:309-314.

Girija C, Smith BN, Swamy PM (2002). Interactive effects of sodium chloride and calcium chloride on the accumulation of proline and glycinebetaine in peanut (Arachis hypogaea L.). Environ Exp Bot 47:1-10.

Guo Z, Huang EM, Lu ES, Yaqing EZ, Zhong EQ (2007). Differential response to paraquat induced oxidative stress in two rice cultivars on antioxidants and chlorophyll a fluorescence. Acta Physiol Plant 29:39-46.

Halliwell B, Gutteridge JMC (1999). Free radicals in biology and medicine. NY, Oxford University Press.

Havlin JL, Beaton JD, Tisdale SL, Nelson WL (2005). Soil fertility and fertilizer. An Introduction to Nutrient Management, Upper Saddle River, Newjersey.

Hernandez JA, Jimenez A, Mullineaux P, Sevilla F (2000). Tolerance of pea (Pisum sativum L.) to long term stress is associated with induction of antioxidant defences. Plant, Cell \& Environment 23(8):853-862.

Kabata-Pendias A, Pendias H (1999). Biogeochemistry of trace elements, PWN,Warsaw, Poland.

Manthey JA, Crowley DE (1997). Leaf and root responses to iron deficiency in avocado.J Plant Nutr 20:683-693.

Marschner H (1995). Mineral nutrition of higher plant. Academic Press, New York.

Mittler R (2002). Oxidative stress, antioxidants and stress tolerance. Trends Plant Sci 7:405-409.

Mohamed AA, Aly AA (2004). Iron deficiency stimulated some enzymes activity, lipid peroxidation and free radicals production in Borago officinalis induced in vitro. Int J Agri Biol 6:179-184.

Morgan JM (1984). Osmoregulation and water stress in higher plants. Ann Rev Plant Physiol 35:299-319.

Nagaraj G (1987). Effect of foliar spray of micronutrients on yield and chemical composition of peanut in calcareous soils. Ann Plant Physiol 2:196-202.

Nakano Y, Asada K (1981). Hydrogen peroxide is scavenged by ascorbate-specific peroxide in spinach chloroplasts. Plant Cell Physiol 22:867-880.

Phutela A, Jain V, Dhawan K, Nainawatee HS (2000). Proline metabolism under water stress in the leaves and roots of Brassica juncea cultivars differing in drought tolerance. J Plant Biochem Biotech 9:35-39.

Pietrini F, Iannelli MA, Massacci A (2002). Anthocyanin accumulation in the illuminated surface of maize leaves enhances protection from photo-inhibitory risks at low temperature, without further limitation to photosynthesis. Plant Cell Environ 25:1251-1259.

Rahimizadeh M, Habibi D, Madani H, Mohammadi GN, Mehraban A, Sabet AM (2007). The effect of micronutrients on antioxidant enzymes metabolism in sunflower (Helianthus Annuus L.) under drought stress. Helia 30(47):167-174.

Ranieri A, Castagna A, Baldan B, Soldatini GF (2001). Iron deficiency differently affects peroxidase isoforms in sunflower.J Exp Bot 52:2535.

Roychoudhury A, Basu S, Sarkar SN, Sengupta DN (2008). Comparative physiological and molecular responses of a common aromatic indica rice cultivar to high salinity with non-aromatic indica rice cultivars. Plant Cell Rep 27:1395-1410.

SAS Institute Inc (2002). SAS System for Windows, Release 9.0. Statistical Analysis Systems Institute, NC, USA.

Schulze ED (1991). Water and nutrient interactions with water stress. In: Mooney HA, Winner WE, Pell EJ (Eds), Response of Plants to Multiple Stresses. Academic Press, San Diego pp 89-101.

Sekmen AH, Turkan I, Takio S (2007). Differential response of antioxidative enzymes and lipid peroxidation to salt stress in salt tolerant Plantago maritime and salt sensitive Plantago media. Physiol Plant 131:399-411.

Selote DS, Khana-Chopra R (2004). Drought-induced spikelet sterility is associated with an inefficient antioxidant defence in rice plants. Physiol Plant 121:462-467.

Senaratna T, McKersie BD (1986). Loss of desiccation tolerance during seed germination: a free radical mechanism of injury. In: Leopold AC (Ed), Membranes, Metabolism and Dry Organism. Cornell University Press, Ithaca and London pp 85-101.

Sharma SS, Schat H, Vooijs R (1998). In vitro alleviation of heavy metal induced enzyme inhibition by proline. Phytochem 49:1531-1535.

Shigeoka S, Ishikawa T, Tamoi M, Miyagawa Y, Takeda T, Yabuta Y (2002). Regulation and function of ascorbate peroxidase isoenzymes. J Exp Bot 53:1305-1319.

Sun B, Jing Y, Chen K, Song L, Chen F, Zhang L (2007). Protective effect of nitric oxide on iron deficiency-induced oxidative stress in maize (Zea mays). J plant physiol 164:536-543.

Thipyapong P, Stout MJ, Attajarusit J (2007). Functional analysis of polyphenol oxidases by antisense/sense technology. Molecules 12(8):1569-1595.

Yoshiba Y, Kiyosea T, Nakashima K, Yamaguchi-Shinozaki K, ShinoZaki K (1997). Regulation of levels of proline as an osmolyte in plants under water stress. Plant Cell Physiol 38:1095-1102.

Zaharieva TB, Abadia J (2003). Iron deficiency enhances the level of ascorbate, glutathione, and related enzymes in sugar beet roots. Protoplasma 221:269-275. 